\title{
Carrying capacity for ecotourism development in Tahura K.G.P.A.A. Mangkunagoro I
}

\author{
Ari Wulandari ${ }^{1}$, Maryono Maryono ${ }^{2}$, and Agus Setyawan ${ }^{3}$ \\ ${ }^{1}$ Master Program of Environmental Science, School of Postgraduate Study Diponegoro University, Semarang - Indonesia \\ ${ }^{2}$ Department of Urban and Regional Palnning, Diponegoro University, Semarang - Indonesia \\ ${ }^{3}$ Department of Physics, Faculty of Science and Mathematics Diponegoro University, Semarang - Indonesia
}

\begin{abstract}
The development of nature tourism in conservation areas such as in Taman Hutan Raya (Tahura) should be able to minimize the negative impact for the ecosystem. Tourism activities on the utilization block of Tahura must be limited by applying ecotourism concept which is concerned with environmental conservation and not the concept of mass tourism that is oriented on the number of visitors. Tahura K.G.P.A.A. Mangkunagoro I, every year has increased the number of tourist arrivals, most occur in 2016 and 2017 that is equal to $62.8 \%$ and $63.5 \%$. This condition harmful the environment if it is not managed in a sustainable way that considers the carrying capacity of its environment. Therefore, a study was conducted to calculate the environmental carrying capacity in the utilization blocks of Tahura K.G.P.A.A. Mangkunagoro I using the method of calculating the physical carrying capacity (PCC), real carrying capacity (RCC) and effective carrying capacity (ECC) with the formula developed by Cifuentes (1992). The results of the calculation of environmental carrying capacity can be used as recommendation of the types of tourist activities that can be done, the arrangement of tourist visits, the type of facility that can be built in accordance with the rules of conservation and the number of officers required.
\end{abstract}

Keywords: carrying capacity; ecotourism; Tahura K.G.P.A.A. Mangkunagoro I

\section{INTRODUCTION}

One of the conservation areas can be utilized for natural tourism exploitation is Forest Park (Tahura). Indonesia recognizes the term conservation area with conservation forest [1]. According to Law no. 41 Year 1999 on Forestry, conservation forest is a forest area with certain characteristics has the main function of preserving the plants and animals' diversity and their ecosystems. Conservation forest consists of:

a. Nature Conservation Area (KSA) consisting of Nature Reserve and Animal Reserve;

b. Nature Conservation Area (KPA) consisting of National Park, Nature Tourism Park and Grand Forest Parks

c. Hunting Park.

In its management, Tahura has an exception managed by the local government. Central Java Province manages 231.3 ha Tahura area and located on the slopes of Mount Lawu which is administratively located in Karanganyar Regency, named as Tahura K.G.P.A.A. Mangkunagoro I [2].

Nature tourism is currently in great demand by the community since offers the nature and uniqueness not encountered in urban areas. Tourism utilizes nature is highly determined by the of environment state since without a good environment tourism will not grow [3]. If the quality of the environment is good, visitors will return visit and vice versa if the environment quality became a tourist attraction damaged it will be abandoned by visitors. Tahura K.G.P.A.A. Mangkunagoro I has strategic value from the aspects of research, education and the environment. The forest covering an area of 231.12 ha has diverse potential in the form of flora and fauna, culture, landscapes, and its function as a regulator of water for the community, storing carbon, and forming a micro climate. Thus, the development of natural tourism especially in conservation areas such as in Tahura must be done carefully with a minimum of negative impact on the ecosystem. Every activity carried out therein must be very limited. Appropriate developed tourism model or concept in Tahura is not a mass tourism concept which is oriented on the visitors' number with significant impact on economic benefits, but ecotourism with special interest tourism activities according to [4] attach importance to education process related to environmental conservation efforts.

Increasing community visits number to tour Tahura K.G.P.A.A. Mangkunagoro I from 2013 to 2017 is quite drastic, especially in 2016 and 2017 of $62.8 \%$ and $63.5 \%$. The average tourist visit to the Mangkunagoro I Tahura in 2013-2017 is 20,049 people/year or 55 people/day, as shown in Table 1 below:

* Corresponding author: ariwulandari.wd@ gmail.com 
Table 1. Data on the number of visitor from 2013 up to 2017

\begin{tabular}{lllll}
\hline No. & $\begin{array}{l}\text { Year } \\
\text { Period }\end{array}$ & $\begin{array}{l}\text { Visitors } \\
\text { Number }\end{array}$ & $\begin{array}{l}\text { Visitors } \\
\text { Increased } \\
\text { Number }\end{array}$ & $\begin{array}{l}\text { Increasement } \\
(\%)\end{array}$ \\
\hline 1 & 2013 & 7.999 & & \\
2 & 2014 & 10.911 & 2.912 & 36,4 \\
3 & 2015 & 15.371 & 4.460 & 40,8 \\
4 & 2016 & 25.029 & 9.658 & 62,8 \\
5 & 2017 & 40.936 & 15.907 & 63,5 \\
\hline \multicolumn{3}{c}{ Source: [2] (though data) }
\end{tabular}

The visitors increasing number contributed positively to the Central Java Province Local Revenue (Pendapatan Asli Daerah /PAD). In 2017, Tahura K.G.P.A.A. Mangkunagoro I contribution for Central Java Province PAD is Rp.165.513.800,00. The increase is not necessarily a positive impact for the environment and may even otherwise have a negative impact, therefore according to [5] required setting the visitors number in accordance to the environment carrying capacity.

In tourism, carrying capacity is important to know since tourism is highly dependent on the environmental quality. Environmental conditions become important to note since the environmental quality disruption of tourist attraction will be disrupted or lost [3]. The tourism carrying capacity plays an important role in the conservation areas management since it is viewed as a systematic, strategic policy tool in the planning process [6]. Calculation of carrying capacity needs to be done to determine the ability to accommodate tourists without causing damage to the environment and visitors comfort. Even the carrying capacity needs to be calculated on a regular basis, according to [7] the carrying capacity concept in tourism understanding is dynamic and not static. A study of Tahura carrying capacity towards visitors was once conducted in 2007.

\section{RESEARCH METHODS}

The area carrying capacity is the ability of the area to accommodate the visitor in performing the activity at the maximum limit due to avoid the environmental quality disturbance and degradation performed by the physical carrying capacity (PCC) calculated based on the comfort extent in the activity, the actual carrying capacity (RCC) is limited by the tolerance level region and the effective carrying capacity (ECC) affected by management capacity.

The data type used in this study is primary and secondary data. Primary data were collected by field observation and survey method, while secondary data was collected by document review and interview. Primary data collection for flora or vegetation species in utilization block using vegetation sampling method done by the plot method in the path, by recording all vegetation in the bottom vegetation form, seedlings, stakes, poles and trees [8]. For fauna data consisting of mammals, reptiles, and insects, a renaissance survey is conducted along with the vegetation inventory or at the bird observation time in the morning and afternoon, and other supporting facilities based on the interview. Secondary data contains data on climate, soil type and slopes.

The analysis method used in this research is quantitative method, counting the number of people who can do activity in block utilization Tahura K.G.P.A.A. Mangkunagoro I based on the developed formula by Cifuentes (1992) and modified by [9].

1. Physical Carrying Capacity (PCC)

$\mathrm{PCC}=\mathrm{A} \times 1 / \mathrm{B} \times \mathrm{Rf}$

Where :

$\mathrm{A}=$ Area of area used for tourism

$\mathrm{B}=$ The area needed by a tourist to travel with still get satisfaction

$\mathrm{Rf}=$ Rotation Factor

\section{Real Carrying Capacity (RCC) \\ RCC $=$ PCC $\times(100-C f 1 / 100) \times(100-C f 2 / 100) \times \ldots .$. $\mathrm{x}(100-\mathrm{Cfn} / 100)$}

As for calculating the correction factor $(\mathrm{Cf})$ : correction factor obtained by considering the variables obtained based on field data are: slope, soil sensitivity to erosion, landscape potential, climate (rainfall). Then calculated correction factor by using the formula as follows:

3. Efective Carrying Capacity /ECC

$\mathrm{ECC}=\mathrm{RCC} \mathrm{x}$ correction factor $(\mathrm{MC})$

MC (Management Capacity) is the managed officers number of the area.

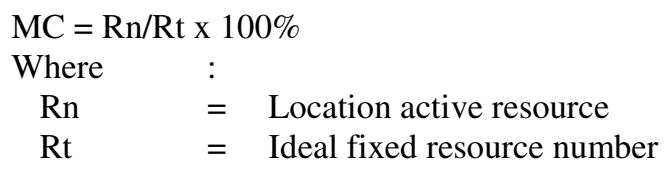

\section{RESULTS AND DISCUSSION}

Tahura K.G.P.A.A. Mangkunagoro I located at 1200 - 1600 mdpl is managed by Central Java Provincial Government with 231.1 ha area based on Minister of Forestry Decree No. 223 / Kpts-II / 2003, divided into Protection Block (94,9 ha), Rehabilitation Block (52,3 ha), Collecting Block (59,6 ha), Utilization Block (21,1 ha), Religious, Culture and History Block (3.4 ha) Governmental administration located in Berjo Village, Ngargoyoso Sub-District, Karanganyar Regency and geographically located $111^{\circ} 813^{\prime \prime}-111^{\circ} 858^{\prime \prime} \mathrm{BT}$ and $7^{\circ}$ 37 '20 "- $7^{\circ} 38$ 33" LS [2].

The utilization facilities available on the utilization block are Bougainvillea Park, Canteen, Guest House, Cottage, Camping Ground Information Center (2 locations), Pendopo, Children's Playground, Animal Demonstration, Deer Cage, Horse Stables, gravel road, Lawu tracking peak (until heading 1), shelter (11 units), arboretum, open stage. In this area will occur the visitor activity, therefore will be calculated the carrying capacity. 


\section{Physical Carrying Capacity (PCC)}

Physical Carrying Capacity (PCC) is the visitors maximum number physically satisfied by the space provided at a given time. In 2007, PCC was calculated with 3,181 visits / days / 231.2 ha [10].

\section{Real Carrying Capacity/RCC}

$\mathrm{RCC}$ is the maximum visitors number allowed to visit Tahura K.G.P.A.A. Mangkunagoro I with correction factor (Cf). RCC's methodology is possible to identify the visitors impact affecting physical factors for the protected areas management [11]. In tourism management, the lowest RCC value is one which limits tourism operations [12]. RCC value calculated in 2007 amounted to 3.104 people / day / 231.2 ha [10].

The effective carrying capacity is related to the number and human resources capacity in providing services to visitors. Moreover, it is known the maximum visits number which not cause disruption to the attraction can be served by the existing officers number with the available management system [13].

In 2007, PCC and RCC carrying capacity were calculated. Tahura K.G.P.P.A. Mangkunagoro I carrying capacity for the flora potential is still low since the block utilization is dominated by Pinus plant, to increase it is necessary to enrich the type towards the Diversity Index (ID) will rise which affect the carrying capacity increase [10]. Carrying capacity calculation of a region is necessary to be done periodically since every change in the tourist attraction will affect the carrying capacity. Each activity in the tourism development effort in Tahura such as the tourism facilities addition and tourism infrastructure will affect the visitors increasing number and tourism activities, the increase will affect PCC, RCC, and ECC value which can lead to increase in carrying capacity or decrease the area carrying capacity. Facilities and infrastructure built in the area must pay attention to conservation interests, for example buildings are made while paying attention to water absorption, minimizing the use of energy and carbon, for example the use of motorized vehicles is replaced with the use of bicycles.

\section{Effective Carrying Capacity /ECC}

The effort of developing tourism in Tahura for ecotourism must pay attention to the conservation rules to preserve the natural resources as the main capital in the nature tourism development [14]. Including the tourist facility addition should be in line to the purpose of establishing Tahura, managers must be able to distinguish the natural parks management by the Forest Park, where conservation and educational functions should be more highlighted than recreation functions. Permenhut P.4 / Menhut-II / 2012 on Amendment to Forestry Minister's Regulation Number P.48 / Menhut-II / 2010 Concerning the Nature Tourism Exploitation in Wildlife Sanctuary, National Park, Forest Park and Nature Park.

Tour model with the visitors' number limitation, tourism activities, means of infrastructures and so on is actually ecotourism contains the development, research concept, and education [15]. In relation to the increase number of visitors exceeds the carrying capacity, necessary to limit the visitors number or make the number arrangement of visitors in order to give a positive impact on the comfort, harmony, and visitors activities [16]. However, for the visits number are seasonal and not occur throughout the year, it does not have much effect on the environment [13].

Tahura increased visit by the tourism promotion of managers to schools, colleges, boarding schools for camping and outbound activities. Nevertheless, the very fast information technology development at this time also affect the tourist visit [15]. Social media is currently a very promising medium for promotion therefore influence on Tahura tourist information dissemination to the public.

\section{CONCLUSION}

The area carrying capacity for the ecotourism development plan in K.G.P.A.A. Mangkunagoro I Grand Forest Park should be assessed in order to minimize the negative impacts on the ecosystem due to tourism activities and construction of facilities and infrastructure in conservation areas. The carrying capacity assessment of visitors has been done in 2007 is different to the current condition, since there are many facilities infrastructures built today. These will certainly affect the tourist visit and affect Tahura carrying capacity area either decrease or increase the area carrying capacity. Natural tourism concession activities should be implemented in accordance to the conservation principles and in accordance to Tahura's main function as a conservation forest to preserve the plants and animals' diversity and their ecosystems.

\section{ACKNOWLEDGMENT}

Part of this research is funded by the Directorate of Research and Community Services, Ministry of Research, Technology and Higher Education for year 2018 with contract number 101-147/UN7.P4.3/PP/2018.

\section{REFERENCES}

1. Hermawan, M.T.T.; Faida, L.R.W.; Wianti, K.F.; Marhaento, H.; Anindia, A., Pengelolaan Kawasan Konservasi. Yogyakarta: Gadjah Mada University Press, 2014.

2. Balai Tahura, Buku Saku Tahura K.G.P.A.A. Mangkunagoro I. Karanganyar: Dinas Lingkungan Hidup dan Kehutanan, 2017.

3. Fandeli, C. dan Suyanto, A., "Kajian Daya Dukung Lingkungan Objek dan Daya Tarik Wisata Taman Wisata Grojogan Sewu, Tawangmangu," Jurnal Manusia dan Lingkungan, vol. Nomor 19 T, pp. 32-47, 1999.

4. Nugroho, I., Ekowisata dan Pembangunan Berkelanjutan. Yogyakarta: Pustaka Pelajar, 2015.

5. Alikodra, H.S., Konservasi Sumber Daya Alam dan Lingkungan: Pendekatan Ecosophy Bagi 
Penyelamatan Bumi. Yogyakarta: Gadjah Mada University Press, 2012.

6. Salerno, F., Viviano, G., Manfredi, E. C., et al., "Multiple Carrying Capacities from a management oriented perspective to operationalize sustainable tourism in protected areas," Journal Environment Management, no. 128 , $116-25$. doi:10.1016/j.jenvman.2013.04.043, 2013.

7. B. Sunaryo, Kebijakan Pembangunan Destinasi Pariwisata: Konsep dan Aplikasinya di Indonesia. Yogyakarta: Gava Media, 2013.

8. Bismark, M, Prosedur Operasional Standar (SOP) untuk Survei Keragaman Jenis pada Kawasan Konservasi. Bogor: Pusat Penelitian dan Pengembangan Kehutanan. Kementerian Kehutanan dan International Tropical Timber Organization, 2011.

9. Fandeli, C dan Muhammad, Prinsip-Prinsip Dasar Mengkonservasi Lanskap. Yogyakarta: Gadjah Mada University Press, 2009.

10. Pramono, B.D., "Kajian Daya Dukung Taman Hutan Raya (Tahura) "Ngargoyoso" Terhadap Pengunjung," UGM, 2007.

11. Aryanto, T., Hartuti P., dan Tri, R.S., "Daya Dukung Jalur Pendakian Bukit Raya di Taman Nasional Bukit Baka Raya Kalimantan Barat," Jurnal Ilmu Lingkungan, vol. Volume 14, no. Issue 2 ISSN 1829-8907, pp. 72-76, 2016.
12. Monteiro, L., \& Silva, C. P. da., "Assessing carrying capacity in protected areas trails: The Formosinho Trail - Arrábida natural Park (Portugal)," in Proceedings Monitoring and Management of Visitors in Recreational and Protected Areas, 2012, pp. 102-103.

13. Hardoyo, D., Fuad M., dan Tukiman, T., "Perencanaan Kegiatan Wisata Pendidikan Dalam Kawasan Geopark Rinjani Lombok Berbasis Daya Dukung Lingkungan (Studi Daerah Air Berik)," Jurnal Ilmu Lingkunan., vol. Volume 14, no. Issue 2 ISSN 1829-8907, pp. 103-107, 2016.

14. Flamin, A., dan Asnaryati, "Potensi Ekowisata dan Strategi Pengembangan Tahura Nipa-Nipa, Kota Kendari, Sulawesi Tenggara," Jurnal Peneliti Kehutanan Wallacea, vol. Vol. 2 No., no. Juni 2013, pp. 154-168, 2013.

15. Muttaqin, T., Hadi, R., Nurul, S., "Kajian Potensi dan Strategi Pengembangan Ekowisata Di Cagar Alam Pulau Sempu Kabupaten Malang Provinsi Jawa Timur," GAMMA, vol. Volume 6, no. Maret, pp. 152-161, 2011.

16. Purwanto, S., Lailan S., dan Andi G, "Kajian Potensi dan Daya Dukung Taman Wisata Alam Bukit Kelam Untuk Strategi Pengembangan Ekowisata," Jurnal Pengelolaan Sumberdaya Alam dan Lingkungan, vol. Vol. 4 No., pp. 119$125,2014$. 